CATALAN REVIEW

Catalan Review

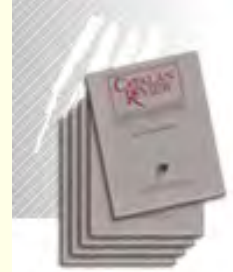

You are accessing the Digital Archive of the Catalan Review Journal.

By accessing and/or using this Digital Archive, you accept and agree to abide by the Terms and Conditions of Use available at http://www.nacs-

catalanstudies.org/catalan review.html

Catalan Review is the premier international scholarly journal devoted to all aspects of Catalan culture. By Catalan culture is understood all manifestations of intellectual and artistic life produced in the Catalan language or in the geographical areas where Catalan is spoken. Catalan Review has been in publication since 1986.
NORTH

AMERICAN

CATALAN

SOCIETY
Esteu accedint a l'Arxiu Digital del Catalan Review

A l' accedir i / o utilitzar aquest Arxiu Digital, vostè accepta i es compromet a complir els termes i condicions d'ús disponibles a http://www.nacs-

catalanstudies.org/catalan review.html

Catalan Review és la primera revista internacional dedicada a tots els aspectes de la cultura catalana. Per la cultura catalana s'entén totes les manifestacions de la vida intel lectual i artística produïda en llengua catalana o en les zones geogràfiques on es parla català. Catalan Review es publica des de 1986.

\title{
Some Types of Short Theatre in Eighteenth-Century Valencia Gabrlel Sansano
}

Catalan Review, Vol. XIX, (2005), p. 265-284 


\title{
SOME TYPES OF SHORT THEATRE IN EIGHTEENTH-CENTURY VALENCIA ${ }^{I}$
}

\author{
GABRIEL SANSANO
}

\section{ABSTRACT}

Traditional history of theatre has doubted the existence of theatrical activity in Catalan in eighteenth-century Valencia. This article highlights the continued presence of an "informal" and Valencian theatre, made up of short pieces; it gives information about actors, audiences and the places where this activity was developed. Finally, it looks at the works staged and proposes a typology of them based on the Castilian dramatic models that the popular actors imitated and mimicked.

\section{INTRODUCTION}

$I_{t}$ is a well known fact that from 1582 Valencia's Hospital Real $i$ General had the privilege of exclusive performance rights of comedies in Valencia. This is why studies of lay theatre have on the whole centred on Valencia's only official theatre, which has provided us with abundant material: the Casa de Comèdies, also known as the Casa de l'Olivera. Its successors, the Botiga de la Balda and the Teatre Principal have also been studied, but to a lesser degree. Studies of seventeenth and eighteenth-century Valencian theatre, from Lamarca and Merimé onwards, have a solid tradition and have given important insights into prohibitions, payments, works staged, types of audience, ticket prices and takings, companies, and so on.

At the same time, it must be noted that despite this bountiful line of research, theatre in Catalan in the Valencian region does not appear anywhere on the official scene: there are no authors, no texts, no places where they could be staged, nor any actors or actresses. This is so much so that it has always been doubted whether there really was a coherent Catalan theatre at that time (or during modern times) given

1. This paper was written within the framework of the research project *Textos básicos de la literatura catalana de la Edad Modernar (BFF 2002-0256I), funded by the Plan Nacional de Investigación Cientifica, Desarrollo e Innovación Tecnológica, Ministerio de Ciencia y Tecnología. 
that it has seemingly never generated any specific documents or, if it has, they have not reached us and have disappeared without a trace.

In the framework of this session on New Directions in Catalan Studies, we propose a new approach to the study of popular theatre in the Pais Valencia throughout the eighteenth century, that is, the study of a type of theatrical activity that until now had been considered as more hypothetical than possible.

\section{The Current State of Knowledge}

\section{Official theatre}

Let us recall that Arturo Zabala (Ópera 16-17) establishes three periods in eighteenth-century Valencian theatre: the first runs from the beginning of the century until 1748-50, the moment when Archbishop Mayoral manages to ban performances throughout what was the Kingdom of Valencia, and manages to get the Casa de Comèdies closed and demolished.

A second period goes from $176 \mathrm{I}$ to 1779 , during which the city's civil and military authorities gained authorisation to resume performances in an old municipal warehouse, known as the Botiga de la Balda. However, following the Zaragoza theatre fire in November 1778 (which caused the death of 80 people), the Valencian theatre was ordered to close in January 1779, given that it was made entirely of wood and the risk of fire was high.

The third period, from 1783 until 1800 , is when there began to be some productions in provisional locations, whilst the Botiga de la Balda, which came back into service in 1785 , was being renovated. In the nineteenth century the Botiga de la Balda maintained its official status until the Teatre Principal was opened in 1832.

The sources relating to these premises have been studied by, amongst others, Eduard Julià, Arturo Zabala, John E. Varey, Francis Sureda, Jean Mouyen and Lucio Izquierdo. Furthermore, there is Jaume Lloret's 2001 study of Alacant's Casa de Comèdies. Finally, it must be noted that knowledge of marginal venues such as the Gran and carrer d'Alboraia theatres is scarce and fragmentary. Regarding the subject matter that interests us here, we recall that Francis Sureda, a researcher in Valencian theatre, states that:

En (...) les quaranta-vuit temporades teatrals durant les quals funcionaren els corrals valencians, entre 1700 i 1779 (..) s'oferiren al públic unes 539 obres dramàtiques (comèdies, sarsueles i actes sacramentals). Cap, pel que sabem, no es representà en llengua valenciana. (...) 
Malgrat les hipòtesis que puguin fer-se, no hi ha cap mena de dubte que, en el transcurs del segle xviii, totes les peces ofertes a tots dos teatres pels actors i les diverses companyies oficials, com també a les places públiques de la ciutat, foren obres dramàtiques representades per actors que provenien molt sovint dels quatre punts cardinals d'Espanya. (310-3ir)

It seems difficult, then, that these venues and these Castilian companies are compatible with a theatre in Catalan. So were there other possible venues, besides the official theatres, where there could be a vernacular theatre?

\section{Home-grown stagecraft}

Joan Fuster was one of the first to pose questions about local theatrical activity in the eighteenth and early nineteenth centuries (97-98), a type of popular theatre which was improvised by the working classes, fundamentally of oral tradition, carried out on the fringe of the learned theatre of the cases de comèdies which was always in Castilian. Fuster, interested in the social history of the language, thought that some sort of theatre must have existed on the fringe of what was performed in the commercial theatres, although not necessarily a formal theatre, "hi bastava el diàleg, la pantomima, potser una dansa amb intercalacions de recitat, una qualsevol paròdia de la «vida» quotidiana amb ganes d'exercitar el sarcasme" (102-103).

It is the same line of investigation as pursued by the historian Ricard Blasco who, until now, is the person who has best studied the world of Valencian col-loquis and col-loquiers, and who has paid most attention to it, as much from the point of view of their prototheatricality, as from the consideration of them as relaters of news and precedents of modern journalism. Blasco also edited two eighteenthcentury col-loquis (one from 1729), which preceded Carles Leon's Junta secreta by some fifty years.

By the way, another matter should be made clear: when talking about col-loquis, which in a certain philological tradition have been considered as displays of the linguistic and literary survival and the vitality of eighteenth-century Valencian poetry (Llombart, Almela i Vives, Sanchis Guarner Valencians), here we follow Fuster and Blasco and are interested in them essentially as wholly dramatic pieces and as a form of Valencian theatre alternative to the official and Castilian theatre. So, we shall not take into account many texts that, although referred to as col-loquis and the like, do not immediately lend themselves to theatre but rely rather on the aforementioned informative characteristic (linked to the romancer tradition); clearly, fully aware of 
the fact that any narrative text, in prose or verse, can be acted out at any time.

The following words by Josep Lluís Sirera are useful in summarising the present state of knowledge and the need to study in depth the dramatic side of colloquis.

[A]quests poemes dialogats, que encara no fa moltes dècades eren recitats $\mathrm{i}$ mimats per uns rapsodes especialitzats (els colloquiers), poden ser considerats-el terme és del mateix Ricard Blasco-com a rudiments del tèatre valencià, del contemporani s'entén.(...)

Siguen antecedents del sainet o no, el que ningú no pot negar és que els col-loquis són una mostra d'una teatralitat a cavall entre el teatre estricte i la poesia oral. I que molt sovint anaven inclosos en contextos festius i espectaculars més amplis; el fet que el col-loqui empre per regla general el romance com a estructura poètica, contribueix també a acostar-lo a les manifestacions dé teatre breu contemporànies. (...) mentre no avancem en el nostre coneixement del teatre en valencià durant el XVIII, haurem de continuar considerant els col-loquis com la principal mostra de teatralitat divuitesca en la nostra llengua. (353)

\section{COL.LOQUIS, A RAGBAG}

Surely the first thing we must do is to discern everything that tradition has placed under the banner of the col-loqui, to see whether they are all the same thing or whether we are faced with different texts. What is a col-loqui? The first to give a definition is Gayano Lluch, according to whom:

El "colòqui" (...) significa "conferencia, confidencia, charla o soliloquio de una, dos o más personas que tratan de algún asunto particular, bien amoroso, punzante o específico", cuyo vocablo procede del latin "colloquium", forma sustantiva de "colloqui", que quiere decir "pensar en alto, razonar, platicar con alguien", palabra que compónese de las raices "col", por "cum", con, y "loqui", hablar, que en nuestra lengua materna derivó, a fines del xVII, a significar "entretenimiento público y agradable lleno de libres expresiones con no poca agudeza y desparpajo"[...] (77)

Amongst Catalan literary historians, Antoni Comas and Ricard Blasco (who defines the terms col-loquier and raonament) more or less coincide with the entry in the Diccionari de la literatura catalana.

Composició popular anomenada també "raonament" o "conversa", escrita sobretot en romanç, que, en general, era recitada davant un públic en places o teatres pel scol-loquiers. Tingueren un apogeu extraordinari al País Valencià a partir del segle XVIII - encara que n'hi ha d'anteriors - i sobretot durant el segle XIX. En general tractaven d'esdeveniments, problemes i preocupacions 
d'actualitat i, en certa manera, complien entre les classes més baixes una funció informativa o de propaganda ideològica (...) Progressivament els colloquis sofriren una teatralització que es manifestà en l'augment d'actors -incloenthi dones-, la utilització de disfresses adequades, etc.; aquesta forma teatral primària fou coneguda com a ‘jocs. $(723-764)$

\section{Fuster recalls that:}

El nom de "colloqui" aplicat a una peça dialogada i adreçada a la representació, el trobem en La Vesita de Ferrandis d'Herèdia, en alguna obra de Joan Timoneda i, sens dubte, degué ser bastant generalitzat a nivell popular per a referir-se a funcions escèniques curtes i de to menor. El cas és, però, que el concepte de "col-loqui" - i dels seus sinònims "raonament" $\mathrm{i}$ "conversació" pren al País Valencià una significació, sinó distinta, més àmplia, a partir de les darreries del segle XVII. (IO4)

Surely it is Rosa Cañada, a researcher into popular literature (literatura de canya $i$ cordell), who has been most concerned with definitions of col-loquis and who has pointed to the multifaceted and borderline character of this sort of text.

Por sus relaciones con otros subgéneros de la literatura de cordel, el colłloqui se sitúa como pieza fronteriza entre los cromances para representar, diálogos y monólogos; englobados en el grupo ‘Romances' de la clasificación hecha por Caro Baroja en su Ensayo sobre la Literatura de Cordel, y los pasos y pasillos adscritos al Cancionero vulgar de diversas composiciones, en la misma clasificación, ya que los textos designados como col-loquis son monólogos o diálogos que varían des de la simplicidad de los primeros, hasta la complejidad de algunos otros con varios personajes, acotaciones, apartes, etc., que constituyen auténticas piezas teatrales, aunque rudimentarias; siendo imprescindible, en todos los casos, el poseer ciertas dotes histriónicas para su representación. (63)

To summarise let us say that it is a type of popular composition, almost always in Romance verse (prose is an exception), realist in character, which when recited or acted out in public was "perceived" as a performance that, sometimes, expanded on certain real or falsified pieces of news, in a satirical or mocking atmosphere, which was always jovial and jocular. The works are rarely fewer than two-hundred or greater than five-hundred lines in length, and the frequently feature second, third and even fourth parts, and as such can surpass one thousand lines. 


\section{A NEW APPROACH}

It seems clear to us that there is mistake in the current stance, which is to consider col-loquis as a semi-theatrical form that is genuinely Valencian and autonomous in itself, without links to other contemporary forms. Instead of following along this path, and taking into account the point of view expressed by Cañada about the borderline character of this type of texts, we believe that it is important to take advantage of the results of research into short Castilian theatre of the Baroque period, because we believe that they can be of great use to study in greater depth our present subject matter. By way of example we point the reader to Emilio Cotarelo, Javier Huerta and the Diccionario de la comedia del Siglo de Oro, where abundant complementary bibliography can be found.

We agree with Fuster that from the seventeenth century concepts such as col-loqui and raonament acquired, amongst Valencians, a more diverse meaning. Up to the point that, as we shall see, the designation col.loqui, and its synonyms, ultimately displaced the names and eliminated differences in the dramatisation of well-known pieces from the Golden Age of Spanish short theatre: moixiganga, xàcara, entremès, lloa, and so on.

The appearance of this type of "Valencian" texts is a process which seems to begin a while before the time stated by Fuster, in the first half of the seventeenth century, and they achieve massive distribution through printing from the second third of the eighteenth century. According to current knowledge, the proliferation of texts begins precisely in the 1730 s and carries on until the 1760 , when it seems to go into decline; things take an upturn in the last quarter of the century, with all sorts of propagandistic aims, and the texts follow on into the nineteenth century, until the Peninsular War (I808-I4) and the uprising of $1820-23$, when the spread of new ideas finds in the col-loquis an efficient tool for political struggle. From the second third of the nineteenth century they again decline.

However, the period of time we shall study here is a century, which is delimited by two texts: the Cal-loqui nou de l'any 1729 , an anonymous work, and Los aficionats a les comèdies, by Pasqual Martínez, which bears no date but is known to have been written in the first third of the nineteenth century.

On the study of this type of works, Sureda points to a possible line of research, even though it is difficult to follow.

Els documents dels arxius de l'Hospital General, relatius al funcionament del teatre, mai no fan menció del teatre menor (sainets o entremesos) que acompanyava la representació de la comèdia. No s'ha d'excloure, doncs, l'eventualitat 
de representacions ocasionals d'aquelles produccions dramàtiques populars, que només podien tenir lloc amb l'acord del director del grup i dels administradors del teatre. Hem trobat exemples de prestidigitadors, d'imitadors de cants d'ocells i de demostradors d'experiències de fenòmens de física, però mai de recitadors de romanços o de raonaments i menys encara d'actors contractats per representar col-loquis en llengua valenciana.

Tota aquella producció devia estar reservada gairebé als auditoris reunits al voltant d'entaulats de saltimbanquis, en ocasió de festes populars de barri o a les places dels pobles. (322-323)

\section{AN INFORMAL THEATRE}

We borrow the term informal from the field of economics, where the concept "informal economic activity" designates a kind of activity aimed at day-to-day survival, which has legal ends but is carried out outside of any sort of legal or labour regulation, and does not appear in official statistics, despite the fact that tax authorities are aware of and tolerate its presence.

In the line pointed out by Sureda, the Catalan theatre to which we shall refer below was staged in private homes and warehouses, it was not "formally" controlled or regulated by municipal authorities or by administrators from the official theatre, the Hospital, who knew of its existence and tolerated performances. It is apparently a home-made theatre, created by enthusiasts, where there were also raffles held in the audience. So we are talking about a fringe theatre, successful amongst the working and middle classes., which had to generate some sort of income, however modest. With the designation of informal stage activity, then, we refer to all those performances which escaped both the control of the Hospital and the prohibitions, and which, despite being known about, were tolerated.

\section{The venues}

There are no documents of any sort about the performances held privately or at fringe venues (el Grau, carrer d'Alboraia), nor is there any study of same kind as Francesc Curet's study of private theatres in seventeenth-century Barcelona. According to Curet, in Barcelona there were some twenty private venues, that can be grouped together "pels locals on estaven emplaçats i segons la classe predominant dels executants o de la concurrència que hi assistia: teatre d'aristòcrates, cavallers i burgesos acabalats; teatre menestral, i representacions que tenien lloc en convents o col-legis religiosos" (59). 
What must Valencia's "private theatres" have been like? John E. Varey, poring over documents from the Hospital, tells of many diverse and often fleeting shows from the sixteenth to the eighteenth century. So, limiting ourselves to this century, as well as the shows that took place at the Olivera, there were also performances in hostels and inns. The inns (fondes) had different economic categories and this fact must have in some way stratified and differentiated the audiences that went there. The audiences at performances by confraries and gremis (silversmiths, shoemakers, etc.) must have been as heterogeneous or even more so; private houses, warehouses (such as $l_{a} P$ alla) and venues like el pla de la Saida and so on are not the only occurrences.

For example, the various prohibitions of comedies have been studied focussing on the repercussion they had on official venues: the Teatre de l'Olivera and the Botiga de la Balda. But it must be said that these same punitive edicts are very useful when looking for alternative venues. A close reading of the complaints from some highly ranked Valencian clergy, from Mayoral onwards, reveals something that we believe is very clear: if they insisted time and again before the Consejo de Castilla, before the king himself that performances should be banned, it is because despite the bans, the closure of theatres and the demolition of cases de comèdies, the show went on in one venue or another.

We must remember that in August 1750 the bishop of Oriola, Gómez de Terán, complained to the king that performances were still going on in towns with the excuse that the ban only affected cities and not towns and smaller places. Two years later, in January 1752 , it was the same archbishop who complained before the king that with the excuse that the ban of performances of 1750 only affected public places, "se representaban comedias en casas particulares, incluso por los carniceros'" (Esquer Torres 1965). They are two very illustrative examples, but they are not alone.

So, the bishop of Oriola, in the letter addressed to the king and his secretary of state, Joseph de Carvajal y Lancastre, complains thus. ${ }^{2}$

[D]ichas comedias en esta mi Diócessis, aunque no se representan por los que son comediantes de oficio, se repiten más públicas, y con más frequencia, que quando libremente se practicaban por aquellas compañías de farssantes en los teatros de Valencia. Pues el enemigo común los ha persuadido a que la Proyivición de su Magestad es a las comedias que questa dinero verlas, y que repressentan los que son de oficio, y no a los [las] que los vecinos de las Villas $y$ lugares quieran repressentar en los theatros que forman en las Plazas, o sitios más capazes donde quepan los pueblos vecinos; repitiendo en dos y en tres días

2. In all quotes the italics and underlining is our own. 
cada uno distinta comedia profana, con el pretexto de que se excuda cada villa o lugar de celebrar a aquel santo, o santa, o festibidad de Nuestra Señora que tiene por titular o Patrono.

The effect of the prohibition could not have been very severe given that, three years later, the same clergyman again insists to the king that all types of performances should be suppressed, and in particular the puppet shows that had been allowed in Oriola. However, on $19^{\text {th }}$ January 1752 archbishop Mayoral wrote:

[P]or un Corral o Patio que se cerró, i que se demolió, i que a costa de crecidos caudales estoi fabricando en su terreno no pocas Casas de Habitación en beneficio de los pobres del Hospital General; suplen al presente diversas casas, en que se representan comedias, $i$ se disponen otras al mismo intento, de suerte que se halla esta ciudad encendida en esta llama, sin que los Superiores $i$ Ministros Reales se opongan a ello, fundados, puede ser, en que en uno de los Decretos de S. Magestad, en que se probiben las comedias por los farsantes en teatros, $i$ por otros particulares, se dice: en parage alguno público, como si en estas palabras se entendiera la probibición solo en calles i plazas públicas, i no en casas, en donde, aunque de particulares, concurre todo género de personas. $\mathrm{Y}$ si en estas se permitieran, pudieran ser de más perjuicio, que los Patios i Corrales, pues a estos se va de día, i se manda salir al anochecer, i se ven las caras; i a aquellas se va mui de noche, i se sale a las onze, doze i una de la noche, siendo assí que en la del Jueves Santo se mandan cerrar las puertas de las Iglesias a las diez, anocheciendo mucho más tarde, que en este tiempo. (...) llegando a tanto, que hasta los cortantes o carniceros han tenido su comedia, que no sé si han concluido las noches de su representación.

Furthermore, some time ago Sanchis Guarner (Inicis I-I2) noted that, faced with the prohibition of performances of comedies instigated by the archisishop, performances moved to private houses, and were staged by amateurs. At the same time he remembered that the rector of the University of Valencia, Friar Vicent Blasco, complained about the proliferation of shows in private theatres in 1770, one year after the death of archbishop Mayoral.

A few years later, the new bishop of Oriola, Josep Tormo, still insisted on the repression of certain public performances until he achieved the Auto del Real Acuerdo de la Audiencia de Valencia... se probiben las funciones de bacas, novillos, comedias, máscara, etc. (1775); a very interesting document, known in part since it was studied by Cotarelo.

As we can see, performances in private houses existed, grew in number and, furthermore, counted on the connivance of the civil authorities. Everything indicates that these performances carried on, and even more so after the eventful life of Valencia's official theatre in the second half of the eighteenth century (Zabala Ópera; Teatro) That 
is why we should not be surprised that the performances reported by Varey and Zabala are precisely from this period.

For example, Zabala points to the fact that when the Balda was closed in 1879 , "algunos grupos aficionados llenaron tan sensible hueco representando en casas particulares y en almacenes cualesquiera" (Ópera 163-164). The most interesting thing, though, is that he transcribes a fragment of a council meeting on $15^{\text {th }}$ April 1785 , according to which:

[S]e había mandado la suspensión de la representación de Comedias en esta ciudad, de lo que havía resultado executarse en casas particulares o Almacenes, por medio de Compañías de Personas aficionadas a dichas representaciones; y aunque se dava el colorido de no pagarse por su asistencia, era notorio que a los que concurrían les era mucho más costoso sin comparación, en consideración al tanto de satisfacción por razón de las boletas que se les dava que, a más, eran tanto más reprobadas por concluirse, por lo regular, a media noche, hora tan incómoda como nada decente a una concurrencia de ambos sexos y sin separación de éstos, dentro del corral o paraje donde se representa. ${ }^{3}$

It must be stated from 1790 the documented appearance of these alternative venues is more regular because, on the one hand, that is the time when the Botiga de la Balda suffered a serious loss of audience and, on the other, because a new written medium, the Diario de Valencia, took charge of collecting these reports and publicising the venues: comic performances, musical concerts, sung performances and so on (Zabala Teatro).

The works staged in private houses during the eighteenth century have already been studied by Juan Antonio Ríos in two separate articles (1988, 1996). In the first he sketches the general features of these pieces, which gives us an idea of what these venues were like: a) they did not need a large stage; $b$ ) there were few actors; $c$ ) there was limited economic investment; d) female roles were not indispensable; e) the plot was simple; f) the work should be accompanied by an introduction (lloa or introit), to present the piece, and a comic sainet; and g) they had to be short.

According to Ríos, the activity was carried out by "grupos de aficionados con un nivel cultural y económico relativamente alto para la época, pero que no dispondrían de verdaderos escenarios ni podrian realizar un dispendio que sobrepasara al propio de una reunión amistosa" (1988:354), and he links these enthusiasts to the literary discussion circles of the eighteenth century. Mutatis mutandis, in Valencia the enthusiasts, in differing degrees, must have been similar.

3. We correct the errors and licences taken in Zabala. See the Arxiu Municipal de València, Libro capitular..., $1785, \mathrm{f} .127 \mathrm{v}-128 \mathrm{r}$. 
The atmosphere at these private functions, in their basic characteristics, could not have been very different from that of the domestic performances that appear in some of Ramón de la Cruz's sainets and some of Mesonero Romanos's articles. The atmosphere described in Pasqual Martínez's Los aficionats a les comèdies and Eduard Escalante's Un trobador en un porxe came a little later.

Finally I believe we must consider another type of stage, also mentioned by Sureda, which is curiously the stage with the most diverse, and at the same time most humble, audience: the street, the stage that goes from the town square to any rural space capable of bringing together an audience around an actor; the theatrical stage in its most primitive and rudimentary sense, which still survived, with different names and forms, in the time that we are studying here.

After everything we have presented here, it seems evident that between the Teatre de l'Olivera and the Botiga de la Balda, and the simple fixed or improvised platform, there existed a whole series of different theatrical possibilities, about which we have only the most fragmentary evidence, given that their commercial "exploitation" must have been an underground affair, or a simple celebrative (and informal, as we have stated) expansion beyond the production of economic gain, which is what most interested the Hospital.

All things taken into consideration, we believe that the data offered here are more than enough to prove the existence of an informal theatrical life, parallel to and beyond the economic control of the Hospital, although not necessarily marginal, in the most pejorative sense of the term. In how many of these venues (private houses, gremis, inns, squares and open spaces) was Valencia's own dramatic output sheltered (or exhaled, as Fuster would say)? With what sort of performances and texts?

\section{The actors and the audience}

The further we go away from commercial and conventional theatre, the less our knowledge of companies, actors and actresses progresses beyond a state of fantasy. What is more, given the individual characteristics of the Grau and carrer d'Alboraia theatres, such as discomfort and distance, we must think that both were rarely frequented by the upper classes, and this lack of noble and bourgeois public was perhaps compensated by the poorer sectors of society, and the quality of companies would run parallel to these economic incentives. Perhaps they frequently relied on the visits of occasional, casual and amateur actors; an improvised group of players which is difficult to study. 
In any case, we should not forget the protests from highly ranked clergy who, as we have seen, complained in the mid-eighteenth century about performances carried out by non-professionals, "los vecinos de las vilas", "personas particulares" and that "no cuesta dinero verlas" in "casas particulares" and the archbishop asked for appropriate punishments for "los que representassen comedias, i a los vecinos en cuyas casa se hiciessen". Various sources allow us insights into these occasional actors and their audience.

There is little information to be able to study this matter in more depth. There is only Ríos's account, and some sparse sources, such as those quoted by Zabala (Ópera I88-24I), taken from the Diario de Valencia. From these we can deduce that in the nineties the enthusiasts already had their own organisation, and they staged performances themselves. So much so that there was even the case that, faced with the serious crisis that the Botiga de la Balda was suffering at the turn of the century, they were brought in to attract city audiences to the theatre, "pues por dos veces vemos anunciada, como aliciente, la participación de aficionados de la ciudad” (239).

\section{THE WORKS: A TYPOLOGY}

In 1990 Joaquim Martí edited a text that has been considered as the first known col-loqui, Rabonament que féu lo jurat de Vinalesa al duch de Arcos, sent virrey de València. Any 1643, which situates this type of text a long time before Blasco and Fuster's suggestions. What interests us here, though, is that this text is very different from normal raonaments, even though it can be linked to the Coloqui nou de l'any 1729 , edited by Blasco, since both feature a clear dramatisation, distancing them from simple romanços.

On the other hand, there is also the "peça xiqueta nova" Més s'aprecien els diners que la sanch y el parentesc (1817), edited by Fuster (166-189). From the second third of the nineteenth century, more or less, the story is known in parts because it is linked to that appearance of new dramatists such as Josep Bernat i Baldoví and Joaquim GarciaParrenyo who, according to Sanchis Guarner (Inicis), represent the beginning of modern Valencian theatre, a period which has already been studied (Sirera, Principal; Blasco; Izquierdo, Teatro 1800-1832, Teatro 1800-1850; Sansano, Obra dramática, Antecedents, Tres notes). The problem was (and is) in being able to give a coherent explanation of Valencia's own theatrical activity, at least between the two dates of 1643 and 1817 . If nothing else, from the eighteenth century we maintain a great number of apparently similar texts, that have been identified as colloquis, raonaments, relacions, converses and so on, which have been 
feasibly considered as a kind of Valencian proto-theatre and which, we believe, are brief dramatic works, as we shall see below.

Our proposal consists of the elaboration of a typology of short dramatic works, normally published individually as col-loquis, taking their sources and the dramtatic models which inspired them as its starting point. Chronologically, the period is delimited by the Coloqui nou de l'any 1729 and the first third of the nineteenth century, approximately when Pasqual Martínez writes Los aficionats a les comèdies. Here and now we shall leave the 1643 raonament to one side, since in this paper we are concentrating on the eighteenth century, and the inclusion of the seventeenth would oblige us to include another set of considerations which would need more space, which unfortunately we do not have.

In elaborating a proposed classification, we have not focussed on the title of each text but rather the source or dramatic model that it follows. As we have seen, performances in private venues were adapted according to circumstances and, so, the differences between the staging of one piece and another were minimal. The only thing that was important was to entertain people in their free time, make people laugh and so everything was changed according to the stage and acting possibilities. The differences between various pieces, on the improvised stage, were levelled out to the basic and necessary minimum. That does not mean that the audience did not organise and attend the performances bearing in mind the original models.

In short, despite the fact that the texts are presented as col-loquis, raonaments, and so on, they respond structurally, thematically, and so on to well-known theatrical genres such as lloes, entremesos, xàcares, etc. Let us look at some examples.

\section{Sources}

We would like to begin this section with one of the final works from our chosen period, because it leads us to ask what that "peça xiqueta" was, where it came from and why. It is no great discovery to point out that Branchart's piece is a work half-way between the Castilian sainete and the quadre de costums. However, it is a curious fact, not noted until now, that Branchart's title echoes the title of a piece by the Castilian Baroque dramatist Luís Vélez de Guevara, Más pesa el rey que la sangre y blasón de los Guzmanes, a work in three acts, which does not present any thematic similarities with the Valencian work. Is this similarity in titles mere chance?

Perhaps not, because as Francis Sureda notes (316), after performances were allowed again in 1761 , a numbered series of comedies was 
printed by the Orga family, which was a stimulus for theatrical activity in the city. It must be noted that the relationship between the printing press and the theatre is a fundamental matter for the study of sources, and even more so in Valencia, one of the principal nuclei for the printing of comedies in the whole of the peninsula.

Fortunately, Jaime Moll's studies have shed a lot of light on this matter in general terms, and also some on the activity of Valencian printers in the publishing of theatre; see also McCready for a more descriptive article on the Orgas' collection. In his research into this collection, Moll complains about not being able to compare their activity with what was being staged in Valencia's theatres at the time, which had hardly been studied then. Many years later, Francis Sureda gives an answer to the possible relationship between what was being staged and what was being published.

La sèrie de comèdies numerades de la impremta valenciana \&Viuda de Joseph de Orga i fills començà el 176r: la seua aparició coincidí amb l'autorització atorgada a la ciutat de representar obres teatrals $\mathrm{i}$ amb l'obertura de la «Botiga de la Baldar, el 23 de març del mateix any. Probablement fou l'impuls donat a la represa de l'espectacle escènic el que va incitar aquells impressors a editar aquella sèrie de comèdies soltes.

(..)

L'impressor tenia tendència a editar, a la vora de tres vegades sobre quatre, aquelles peces que no havien estat utilitzades mai per les companyies, o en poques ocasions. Potser perquè la seua absència als repertoris o la seua aparició de curta durada al teatre les convertien en una raresa $i$, per tant, $\pi$ 'augmentaven el valor. L'afeccionat a les comèdies se sentia incitat probablement a adquirir més aviat aquelles peces que eren molt menys conegudes a València que aquelles que podia veure o reveure en el transcurs de cada temporada. (316)

Vélez de Guevara was a well-known author on the Valencian scene, and many of his works were performed. However, the title that interests us here does not appear in any of the published bills of the Olivera or the Balda, but it was printed in an edition by Josep and Tomàs d'Orga, in 1774. It seems, then, that Branchart took advantage of the effect, be it large or small, that an author and title known to lovers of comedies would have. This is not the only case.

\section{An example}

If we take a look at the titles that I have brought together here, we immediately see how some of the works are related to printed works. The first work, Passet de Toni i Manena, tret del 'Desdén con el desdén, is by Agustín Moreto and was performed thirty-seven times in 
Valencia during the eighteenth century (Julià, Preferencias), but amongst the various published versions we have not found a single Valencian one, even though it was distributed in this format (Moll). The second is Pasillo del Princip y Margarita, tret del en castellà, 'Mudanzas de la fortuna y firmezas del amor', a Baroque work by Christóbal de Monroy, which was not performed in Valencian theatres but was published by the Orgas in 1768 (Sansano, Òbra dramàtica). A third case is Col-loqui del torn de les monches de Sent Christòfol, which partially recreates the Castilian comedy Lo que passa en un torno de monjas, in three acts, starting from a single-act version which was available as a single edition, and a lloa which was available as a manuscript. The other case is the Col-loqui de col-loquis, o encisam de totes herbes, a popular work amongst col-loquiers with various echoes, and which finds its antecedent in the series of romanços and short pieces which were arranged according to the titles of other works, such as the Entremés de los romances by Miguel de Cervantes, and its direct source is in the romances con titulos de comedias and ensaladas. All these texts have been edited recently by Martí Mestre (1996), from a point of view which is eminently that of the history of the language.

It is a different case for xàcares, pieces that recreate the adventures of a wrong-doer or a brave soul from the world of crime: these do not have direct sources, but they do follow a dramatic model. This is the case of Junta secreta by Carles Leon, Parranda i Bufalampolla vénen del Norte..., Raonament $i$ col-loqui nou de Nelo el Tripero by Pasqual Martínez and nearly all the works that use similar characters.

Bearing in mind Javier Huerta's considerations (73-77), we can even propose the hypothesis of moixigangues, a genre belonging to the time of carnival or based on purely festive and scatological elements, with works such as Parlament curiós y entretengut per a desfrés de les Carnistoltes, en que un llaurador va curruquechant a una dama, explicant-li son amor..., Paper molt graciós, discursiu, enfàtic, alusiu y sintenciós, per a desfresar-se de llaurador y dir-lo a les Carnistoltes o en qualsevol atra funció particular, and Coloqui Nou dels Carafals, en el que es referix el chasco que li va pasar a un fadri del horta de Campanar anant a veure els bous.

Other cases are the Col-loqui de l'escolà $i$ la viuda, que es casà a l'instant, Mataraca d'un mossot $i$ un estudiant and Colloqui de la Loteria $i$ chasco de Bolichos, a version of the Castilian sainete, El dia de Loteria, followed by El chasco del sillero, both published by Piferrer in Barcelona and the end of the eighteenth century.

These are only a few examples of the thirty-or-so titles that can be put forward, whilst trying to avoid better-known texts: Misteris del Corpus, Rosíalasà, la Molinera, Pep de Quelo, an so on. All these texts make it clear that there was regular stage activity, although not during the period we are looking at here. 
If we are interested in a second title by Pasqual Martinez, Los aficionats a les comèdies (c, 1840), it is because it graphically separates what is a certain practice belonging to the eighteenth century and rooted in short theatre, from what is already at that time a clearly nineteenth-century concept of home-grown comedies and the quadre de costums, despite being linked to earlier authors such as Ramón de la Cruz.

It must be said that apart from a theatrical spectacle ruled by the Baroque (lloa, first act, entremès, second act, sainet, etc.), it is difficult to create an aseptic taxonomy for all short pieces, because this sort of performance always varied according to circumstances, the possibilities of the domestic stage and the amateurs. What we mean is that if we wish to differentiate between a lloa entremesada and an entremès, we can only really do so starting from the venue where the performance took place: and we know nothing about that. Within the framework of a performance made up exclusively of short pieces, these differentiations are very clear.

Nevertheless, according to what we have said until now, we propose this first typology of short pieces in the eighteenth century.

A typology according to sources (eighteenth - nineteenth century)

\begin{tabular}{|c|c|}
\hline A. Lloes & $\begin{array}{l}\text { 1. Coloqui del torn de les monches de Sant Christòfol } \\
\text { 2. Coloqui per a la Festa de Nostra Senyora de la } \\
\text { Esperanza en lo any i7zo que es féu dins lo Convent de } \\
\text { Senta Úrsula en València, by José Vicente Ortí Mayor } \\
\text { 3. Paset de Toni y Manena, tret del .Desdén con el desdén, } \\
\text { 4. Pasillo del Princip y Margarita, tret del en castellà, } \\
\text { rMudanzas de la fortuna y firmezas del amor, } \\
\text { 5. Coloqui de coloquis o Encisam de totes herbes }\end{array}$ \\
\hline B. Entremesos & $\begin{array}{l}\text { 6. El Coloquio que se sigue bablan sus personajes en } \\
\text { nuestra lengua materna y es el siguiente al romance, } \\
\text { pues babla de las riñas, que bubo, que es lo último a que } \\
\text { llegaron las competencias. Dice así. Coloqui nou de } \\
\text { l'any r729. } \\
\text { 7. Coloqui entretengut, hon se reciten algunes de les } \\
\text { moltes rinyes que solen passar entre les Sogres y Nores, } \\
\text { by Carles Ros. } 758 \\
\text { 8. Entremés de la Sogra y Nora }\end{array}$ \\
\hline
\end{tabular}




\begin{tabular}{|c|c|}
\hline C. Xàcares & $\begin{array}{l}\text { 9. Chunta secreta, o arenga crítica y divertida, que fan sis } \\
\text { personats de distinguit caràcter en la ciutat de Valènsia, } \\
\text { queixan-se àgriament de la mala estació del temps..., by } \\
\text { Carlos Leon, } 1788 \\
\text { 10. Parranda y Bufalampolla vénen del Norte, cridats de } \\
\text { Cento y Tito. El quatre formen un platicó ensomiat, } 18 \mathrm{n} \\
\text { 11. Rahonament y Coloqui Nou de Nelo el Tripero, by } \\
\text { Pasqual Martínez Garcia }\end{array}$ \\
\hline D. Moixigangues? & $\begin{array}{l}\text { 12. Parlament curiós y entretengut per a desfrés de les } \\
\text { Carnistoltes, en que un llaurador va curruquechant a } \\
\text { una dama, explicant-li son amor... } \\
\text { 13. Paper molt graciós, discursiu, enfátic, alusíu y sintenciós, } \\
\text { per a desfresar-se de llaurador y dir-lo a les Carnistoltes } \\
\text { o en qualsevol atra funció particular } \\
\text { 14. Coloqui Nou dels Carafals, en el que es referix el chasco } \\
\text { que li va pasar a un fadrí del horta de Campanar... [c. } \\
\text { I780] }\end{array}$ \\
\hline E. Other & $\begin{array}{l}\text { 15. Matraca de un Mossot y un Estudiant } \\
\text { 16. Coloqui del Escolà y la Viuda, que es casà al instant } \\
\text { 17. Coloqui Nou del Dia de la Loteria i chasco de Bolichos } \\
\text { 18. Los aficionats a les comèdies, by Pasqual Martinez } \\
\text { Garcia }\end{array}$ \\
\hline
\end{tabular}

\section{CONCLUSIONS}

When all is taken into account, it seems clear that a home-grown theatre survived in these domestic, urban and rural ambits (gremis, inns, squares, warehouses, private houses), where because of an anniversary, the head of a gremi, or a harvest, with scarce resources they put together "una cuina a la llauradora del millor modo composta", as Branchart says in the stage directions of his "peça xiqueta", or any other simple and costumista scene, as simple as the stage directions of these short pieces and as basic as the actors.

Various works show that there were people who wanted to stage and see staged in their own language works that others saw at the Balda or read in single editions, and there were amateurs and occasional actors who calqued forms and themes from Baroque Castilian theatre to satisfy this demand. The dramatic texts, which went under the name of col-loquis and raonaments, were performed by actors, both good and 
bad, who came from the community itself. It is clear that both the actors and the audience bore the original Baroque models in mind.

We do not think it is an exaggeration, then, to state that we have here a coherent short theatre, and that it is about time to begin to designate these texts as short theatre, or short comic theatre as Antoni Serrà does when talking about Majorcan entremesos. However, we must be aware that some of these pieces, and others from the seventeenth century, were not always comic in character.

Nevertheless, it is too soon to make an evaluation, because first we must analyse the dramatic and comic mechanisms which articulate each text and prepare real theatrical editions. Furthermore, research must continue and the works must be situated in line with the festive calendar, especially in the case of moixigangues, because then perhaps we would obtain complementary information to make a global evaluation.

Finally, this proposed typology, on the one hand, aims to work towards putting order to the colloquis ragbag, which philological tradition had developed from all those pieces in Romance that they did not know how to classify nor how to read, On the other hand, this vision of the works can stimulate research because it proposes a different approach which we can use to talk, debate and see whether we are able to elaborate a coherent panorama of what Catalan theatre actually was during the modern age.

GABRIEL SANSANO UNIVERSITY OF ALACANT/IIFV (Translated by Richard Mansell)

\section{WORKS CITED}

Almela I Vives, Francesc. Panorama històric de la literatura valenciana. Valencia, 1955.

BLASCO, Ricard. La insolent sàtira antiga. Xàtiva, 1985.

CAÑADA, Rosa. "El coloqui valenciano en los siglos XVIII y XIX." Actas de las Jornadas sobre Teatro Popular en España. Eds Joaquín Álvarez Barrientos and Antonio Cea Gutiérrez. Madrid: CSIC, 1987. 85-107.

Cañada Solaz, Rosa. "Coloquio." Diccionario de la Literatura Popular Española. Salamanca: Ediciones Colegio de España, 1997. 6365.

CASA, Frank P. et al., eds. Diccionario de la comedia en el Siglo de Oro. Madrid: Castalia, 2002. 
Comas, Antoni. "La poesia al País Valencià. Els col-loquis." Histồria de la Literatura Catalana. Vol.4. Barcelona: Ariel, 198r[1964]. 723-764. COTARELO MORI, Emilio. Colección de entremeses, loas, bailes, jácaras $y$ mojïgangas... 2 vols. Madrid, 1911.

CURET, Francesc. Teatres particulars a Barcelona en el segle XVIIIé, Barcelona, 1935 .

EsQUer TORRES, Ramon. "Las prohibiciones de comedias y autos sacramentales en el siglo XVIII." Segismundo 1.2 (1965): 187-226.

FUSTER, Joan. "Plantejaments històrics del teatre valencià." La decadència al País Valencià. Barcelona: Curial, 1976. 27-113.

Gayano Lluch, Rafael. "El "Colòqui» y los Coloquieros." Almanaque Las Provincias 1949. 1949. València: F. Domenech, 75-82.

HuerTa Calvo, Javier. El teatro breve en la Edad de Oro. Madrid: Eds. del Laberinto, 2001 .

IZQUIERDO, Lucio. "El teatro en Valencia 1800-1832." BRAE. Vol. 69 (1989): 257-305.

-. "El teatro menor en Valencia (1800-1850)." Revista de Literatura 52.103 (1990): 10I-127.

Julia Martínez, Eduardo. "Preferencias teatrales del público valenciano en el siglo XVIII," RFE. Vol. 20. (1933): 113-I59.

Llombart, Constantí. Los fills de la Morta-viva. Apunts bio-bibliogràfichs... València, 1879 [1973].

LLORET ESQUERDO, Jaume. "La casa de comèdies d'Alacant (IG161793)." El teatre català antic, dels origens al segle XVIII. Eds A. Rossich et al. Kassel, 200r. 313-345.

Marti Mestre, Joaquim. "Un col-loqui valencià del segle xvil." Caplletra 9, 1990, 129-145.

- - ed. Col-loquis eròtico-burlescos del segle XVIII. València: Edicions Alfons el Magnànim/IVEI, 1996

MCCready, W.T. "Las comedias sueltas de la casa de Orga." Homenaje a William L. Fichter. Estudios ... Madrid: Castalia, 1971. 515-524. MoLas, Joaquim and Josep Massot i Muntaner, eds. Diccionari de la literatura catalana. Barcelona: Edicions 62, 1979.

MOLL, Jaime. "Catálogo de Comedias sueltas conservadas en la biblioteca de la Real Academia Española." BRAE. 44.171 (1964): 113-168; 44.172 (1964): 309-360; 44.173 (1964): 541-556; 45:174-75: (1965): 203-235; 46.177 (1966): $125-158$.

- "La serie numerada de comedias de la imprenta de los Orga." $R A B M$. $75.1-2$ (1968-1972): $365-456$.

Rios CarratalÀ, Juan Antonio, "La obra de José Concha destinada a los teatros particulares", en Coloquio Internacional sobre el Teatro Español del siglo XVIII. Bolonia, 15-18 de Octubre de 1985, Piovan Ed., Abano Terme, 1988, 35I-366.

Rios Carratal $\lambda$, Juan Antonio, "Las obras para casas particulares de 
Antonio Rezano Imperial ${ }^{\text {, }}$, en Josep Maria Sala Valldaura (ed.), Teatro Español del siglo XVIII, Universitat de Lleida, Lleida, 1996, vol. II, 687-705.

SANCHIS GUARNER, Manuel. Els valencians i la llengua autòctona durant els segles XVI, XVII $i$ XVIII. Valencia, 1963.

-. Els inicis del teatre valencià modern, 1845-1874. Valencia, 1980.

SANSANO, Gabriel. "L'obra dramàtica valenciana de Bernat i Baldoví i

la tradició festiva dels colloquiers." Quaderns de Sueca. 13 (1997): 7-32.

—. "Sobre els antecedents dramàtics de Josep Bernat i Baldoví," Bernat $i$ Baldoví $i$ el seu temps. Ed. M. Nicolás. Valencia: Universitat de València, 2002. 429-448.

-. "Tres notes sobre l'actor Joaquim Garcia-Parrenyo i la seua obra Vicenteta la de Patraix (1845)." Professor Joaquim Molas. Memòria, escriptura, Història. Vol. 2. Barcelona: Publicacions Universitat de Barcelona, 2003. 969-983.

SIRERA, Josep-Lluís. "El Principal de València $i$ les representacions teatrals en valencià durant el segle XIX." Estudis Escènics 24 (1984): 77-92.

-. Història de la literatura valenciana. Valencia: IVEI, 1995.

SUREDA, Francis. "Literatura i societat." Història del País Valencià. Volum. 4: L'època borbònica fins a la crisi de l'Antic Règim. Vol. 4. Ed. M. Ardit. Barcelona: Edicions 62, 1990. 310-3II.

- Le théâtre dans la Societé Valencienne du XVIHe Siècle. Perpignan: Presses Universitaires, 2004.

VAREY, John E. "Titiriterros y volantines en Valencia 1585-1785." RVF 3 (1953): $215-276$.

ZABALA, Arturo. La ópera en la vida teatral valenciana del siglo XVIII. Valencia, 1960.

-. El teatro en la Valencia de finales del siglo XVIII. Valencia, 1982. 